\title{
Internalizing Contestation in Process-Based Judicial Review
}

\author{
Laura M. Henderson*
}

(Received 06 June 2018; accepted 27 July 2018)

\begin{abstract}
The cases challenging the European Stability Mechanism in Eurozone creditor states show the concern courts have with protecting and promoting democratic contestation. This Article shows how John Hart Ely's theory of process-based review provides the theoretical basis for understanding how attention to democratic contestation contributes to the legitimacy of courts reviewing legislation against constitutional norms. By focusing on promoting democratic procedures, Ely argues that courts can avoid substantive decisions that are best left to the legislature. Yet, as my discussion of the constitutional theory of constituent and constituted powers shows, no form of constituted power can avoid some exercise of constituent power. In other words, even a process-based approach cannot avoid substantive judgments. The legitimacy of these decisions depends on the availability of avenues for contestation in the judicial decisionmaking process itself.
\end{abstract}

Keywords: Judicial review; democracy; legitimacy; decision-making; Eurozone debt crisis

\section{A. Introduction}

The Eurozone debt crisis has challenged the boundaries of EU and Member State law, and courts have played a key role in this process. In the creditor states of the Eurozone, a broad debate has been waged about the effect of the most important permanent crisis measure-the European Stability Mechanism ("ESM")—on the creditor states' right to democracy. This debate has largely taken place in the courtroom, as the ESM has been the subject of constitutional challenges in Austria, Belgium, Estonia, Germany, Ireland, and the Netherlands. In this Article, I argue that these cases from Eurozone Member States' courts reveal something about constitutional democracy that is often overlooked: The ungrounded nature of constitutional foundations. I argue that this_-inevitably_-demands from the judge a role as both a constituted and a constituent power.

The role of the judge as constituent power, in addition to constituted power, is one that legal constitutional theorists often try to avoid. ${ }^{1}$ One particularly elegant attempt to eliminate all lawenacting power from judicial review was made by John Hart Ely. Ely argued that constitutional review of legislation can be justified only if it does not substitute the values of the people for that of the judge but rather is done only to preserve and protect the proper functioning of the democratic process. ${ }^{2}$ Ely's process-based review sees judges as entrusted with the responsibility to ensure that

${ }^{\star}$ Dr. Henderson is an assistant professor at the Netherlands Institute of Human Rights (SIM) at Utrecht University and a research fellow at the Centre for Global Challenges. I owe particular gratitude to Dr. Luigi Corrias for the conversations we have had about constituent and constituted powers and for introducing me to the work of Claude Lefort.

${ }^{1}$ Martin Loughlin, The Concept of Constituent Power, 13 Eur. J. POL. Theory 218, 222-23 (2014).

${ }^{2}$ See generally John Hart Ely, Democracy and Distrust: A Theory of Judicial Review (1980). 
the challenged law was enacted via a democratic process that included adequate possibilities for those affected by the law to influence the legislative process. Moreover, the judge must ensure that the law itself does not unduly limit the ability of a certain group or individual to participate in the democratic process. Ely argues that if the judge focuses on only the democratic process, the judge can avoid all substantive or political decisions, or decisions that are for the constituent power-the people-to make. Process-based review would thus allow the judge to remain firmly within the limits of her role as constituted power.

It is precisely this process-based approach to constitutional review that is mirrored in many of the Eurozone Member State courts' judgments on the ESM. Yet, while Ely's theory claims to solve the tension between constituted and constituent power and while his approach seems to match what many of the courts studied here see themselves as doing, my analysis of the concrete cases in which such a process-based review is used will show that judges, even here, cannot avoid making substantive decisions. Despite judges' best attempts to avoid substantive decisions and focus only on preserving the functioning of the democratic order, the ungrounded nature of this very order makes it inevitable that these decisions contribute to the constitution of this order. If this is the case, the question becomes: How can the judge legitimately engage in such behavior?

This Article attempts to answer this question as follows. Part B sets the stage by providing a short overview of the adoption of the ESM Treaty and sets out how the national courts' judgments on the ESM Treaty largely reflected a process-based approach to constitutional review. Importantly, the aim of Part B is not to repeat the thorough legal analysis of others, ${ }^{3}$ but rather to show how the judges in these judgments engaged with their conception of their democratic mandate to review parliamentary legislation against higher norms. Part $\mathrm{C}$ proceeds to challenge the assumption that process-based review avoids substantive decisions by linking Ely's theory to the constitutional theory of constituent and constituted powers. I end Part C by arguing that the utility of process-based review can be realized only if courts expand their concern for the preservation and promotion of democratic contestation to include concern for the input into their own decision-making. Part D concludes the Article.

\section{B. Process-Based Review of the European Stability Mechanism}

After a number of temporary measures to deal with the Eurozone debt crisis proved inadequate, ${ }^{4}$ the Eurozone States signed an initial treaty on a European Stability Mechanism (ESM) in July 2011, before signing the final version of the Treaty in February 2012. The Treaty binds all Eurozone Member States to make a predetermined amount of capital available to the Treaty body. The Treaty body is authorized to decide when to distribute parts of this capital to Member States in financial need. Most likely, the Treaty body would distribute the capital as a loan under the strict condition that the receiving state agree to certain reforms decided by the EU Commission. The ESM provided financial assistance to Spain, Cyprus, and Greece after its establishment on September 27, 2012. ${ }^{5}$

This EU crisis measure has been the subject of much litigation, both at the level of the individual Member States and at the EU level. In 2012, the Estonian Supreme Court, the German Constitutional Court - in a preliminary judgment, the Dutch District Court of The Hague, the Irish Supreme Court, and the Belgian Constitutional Court all dealt with claims brought against the ESM Treaty. After a preliminary reference from the Irish Supreme Court, the Court of Justice

\footnotetext{
${ }^{3}$ For an in-depth legal analysis of the ESM and the ESM cases, see generally Claire Kilpatrick, On the Rule of Law and Economic Emergency: The Degradation of Basic Legal Values in Europe's Bailouts, 35 OXFORD J. LEGAL STUD. 325, 325 (2015); Claire Kilpatrick, Are the Bailout Measures Immune to EU Social Challenge Because They Are Not EU Law?, 10 EUR. Const. L. Rev. 393, 393 (2014); Mattias Wendel, Judicial Restraint and the Return to Openness: The Decision of the German Federal Constitutional Court on the ESM and the Fiscal Treaty of 12 September 2012, 14 GERMAN L.J. 21, 21 (2013).

${ }^{4}$ See Kilpatrick (2015), supra note 3, at 326-37 for a detailed overview of the bailout history.

${ }^{5}$ European Stability Mechanism, History: The Programmes, https://www.esm.europa.eu/about-us/history\#the_programmes.
} 
for the European Union ("CJEU") ruled on the compatibility of the ESM with EU law on November 27, 2012. In 2013, the Austrian Constitutional Court followed with its own judgments on the ESM, and in 2014, the German Constitutional Court ruled on the ESM in main proceedings. In this Article I will analyze the rulings by the German Federal Constitutional Court, the Irish Constitutional Court, the Estonian Constitutional Court, and the Dutch District Court for The Hague. This Article does not analyze the case brought before the Belgian Constitutional Court, as it was declared inadmissible on procedural grounds and no substantive considerations were given by the court. ${ }^{6}$ I also exclude from my analysis the decision by the Austrian Constitutional Court as, unlike the cases from the German and Estonian courts-which are also published in English - this document was not available in a language I read.

The national judges that heard these challenges to the Eurozone crisis measures largely positioned their review as a limited interference: The review was limited to what was necessary to ensure the proper functioning of democratic processes. In this way, but without explicit reference, these decisions parallel John Hart Ely's theory of process-based judicial review. This Part shows how the national courts' decisions fit within Ely's theory of judicial review. By doing so, this Part provides necessary background for the remainder of this Article, which will challenge the assumption that such process-based review really can be free of political decisions and will proceed to ask how to best legitimate such constituent moments.

Ely's theory aimed to provide a justification for judicial review of democratically adopted legislation. While Ely accepted that judges who apply higher constitutional norms to override democratically adopted legislation are confronted with norms that are often open-textured and broad, he argued that the discretion judges use to fill in these open-textured norms must be focused on providing neutral rules for the operation of democracy. In an attempt to constrain the indeterminacy of law, Ely proposed that judges not search for or rely on any "external source of values"7 to shape their decision, but instead act purely in service of the democratic process. ${ }^{8}$ For Ely, protecting "the process by which the laws that govern society are made" meant "ensur[ing] that the political process ... was open to those of all viewpoints" and that this political process did not lead to disparate treatment for groups just because of majority biases against those groups. ${ }^{9}$ The main focus in protecting the democratic process was thus to ensure that processes were in place that served to reinforce representation of those taking part in the democratic process. From this perspective, Ely argued that process-based review tasked courts with the very thing they were uniquely suited to do: Use their position as relative political outsiders-who are, in any case, independent from current political power holders - to objectively assess whether the current majority is (ab)using its power by restricting the political process. According to Ely, illegitimate restrictions of the political process would "ensure that [current political power holders] will stay in and the outs will stay out," or systematically disadvantage a minority group "out of simple hostility or a prejudiced refusal to recognize the commonality of interests." ${ }^{10}$ For Ely, judicial review that focused on ensuring processes of representation reinforcement was the only way that judges could avoid the illegitimate substitution of their own substantive value judgments for those of the democratically elected legislature. ${ }^{11}$

In each constitutional challenge to the ESM studied here, the plaintiffs positioned their claims within a discourse of a right to democracy and called upon the courts to help enforce this right, framing it as a right to domestic, parliamentary democracy. The focus was placed on alleged

\footnotetext{
${ }^{6}$ Grondwettelijk Hof [GwH] [Constitutional Court] decision no 156/2012, Dec. 20, 2012, http://www.const-court.be/public/n/ 2012/2012-156n.pdf (Belg.).

${ }^{7}$ ELY, supra note 2, at 73 .

${ }^{8}$ ELY, supra note 2, at 73 .

${ }^{9}$ ELY, supra note 2, at 74 .

${ }^{10} \mathrm{ELY}$, supra note 2, at 103.

${ }^{11}$ ELY, supra note 2, at 67.
} 
violations by the ESM Treaty of the right of the national parliament to determine the budget, ${ }^{12}$ the parliament's right to information, ${ }^{13}$ state sovereignty, ${ }^{14}$ and EU law. ${ }^{15}$ In many of the decisions from the national judiciaries on the ESM Treaty, the courts justified their interference in the democratic process, or lack thereof, with considerations similar to those that underpin Ely's process-based review. Thus, while all Member State courts declined to declare the ESM Treaty unconstitutional, they all also availed themselves of the opportunity to reflect on the particular role the court must play in upholding democracy. The German Constitutional Court was the most explicit about its role as the protector of the democratic process, explaining that, in principle, the court must give priority to the parliament's decision-making powers in adopting the ESM Treaty:

[I]t is primarily the duty of the legislature to weigh whether and to what extent, in order to preserve the discretion for the democratic shaping of affairs and making of decisions, commitments with regard to spending behavior should be entered into for the future .... In this connection, the Federal Constitutional Court may not with its own expertise usurp the place of the legislative bodies, which are first and foremost entrusted with this. ${ }^{16}$

The German Constitutional Court acknowledged that it was primarily up to the parliament to balance competing interests, and that the court must not replace the parliament's judgment with its own. Here, the court's position is similar to Ely's: The parliament—not the courts—is to be entrusted with such matters, because it is the parliament that is directly democratically legitimated. ${ }^{17}$ This attitude is evident, moreover, when the court dealt with assessments of risk on which there was no clear consensus among experts. The German Constitutional Court deferred to the legislature's assessment of the risks of the ESM and of economic instability, refusing to put the court's own judgment on this matter above that of the parliament's:

[T]he Bundestag and the Federal Government stated in detail that the risks involved with making available the German shares in the European Stability Mechanism were manageable, while without the granting of financial facilities by the European Stability Mechanism the entire economic and social system was under the threat of unforeseeable, serious consequences. Even though these assumptions are the subject of great controversy among economic experts, they are at any rate not evidently erroneous. Therefore the Federal Constitutional Court may not replace the legislature's assessment by its own. ${ }^{18}$

\footnotetext{
${ }^{12}$ See Rechtbank Den Haag [District Court of the Hague], Case No. 419556 / KG ZA 12-523, June 1, 2012, para 2.2, https:// uitspraken.rechtspraak.nl/inziendocument?id=ECLI:NL:RBSGR:2012:BW7242 [hereinafter Judgment of June 1, 2012]. The right to parliamentary budgetary autonomy is set out in Article 105 of the Dutch constitution. Although Wilders also submitted other claims, this was the main claim addressed in this case. See also Riigikohus [Estonian Supreme Court] en banc, Case No. 3-4-1-612 Request no. 8 of the Chancellor of Justice of 12 March 2012, July 12, 2012, para. 4, https://www.riigikohus.ee/en/constitutionaljudgment-3-4-1-6-12 [hereinafter Judgment of July 12, 2012]; Pringle v. Government of Ireland [2012] IESC 47, para. 10 ii, http:// www.courts.ie/Judgments.nsf/WebJudgmentsByYearAll/DB079F79BE08A50E80257A9C004F4975?opendocument [hereinafter Judgment of Oct. 19, 2012].

${ }^{13}$ Bundesverfassungsgericht [BVERFG] [Federal Constitutional Court], Case No. 2 BvR 1390/12, para. 157, (Sept. 12, 2012), http://www.bverfg.de/e/rs20120912_2bvr139012en.html [hereinafter Judgment of Sept. 12, 2012].

${ }^{14}$ The ESM Treaty allows a departure from unanimous decision-making in times of emergency, which has raised concerns about decisions that undermine state sovereignty and the right to democracy. These concerns were especially emphasized by the plaintiffs in Judgment of Oct. 19, 2012 at para. 10.ii and in Judgment of July 12, 2012 at paras. 141-53. Moreover, the plaintiffs claimed that the ability to suspend voting rights in the ESM Treaty Body if a Member State defaults on its obligations was a violation of the right to democracy. See Judgment of Sept. 12, 2012 at para. 156.

${ }^{15}$ The issues regarding the relationship between the ESM and EU law will not be discussed in this Article.

${ }^{16}$ Judgment of Sept. 12, 2012 at para. 228 (emphasis added).

${ }^{17}$ ELY, supra note 2, at 67.

${ }^{18} \mathrm{Judgment}$ of Sept. 12, 2012 at para. 271 (emphasis added).
} 
In addition to emphasizing the limits to its review, the German Constitutional Court noted that deference to the legislature is not always appropriate on all matters. According to the court, the judiciary has a legitimate role to play when it comes to ensuring the preservation of democratic procedures. Here, the German Constitutional Court strongly echoes Ely, seeing itself as having a special duty to "ensure that the democratic process remains open and that legal re-evaluations may occur on the basis of other majority decisions, and that an irreversible legal prejudice to future generations is avoided." ${ }^{19}$ This approach is clear in the German Constitutional Court's ruling, on summary review, that the German government must ensure that no provision of the Treatyespecially the Treaty's provisions on professional secrecy-may be interpreted to "stand in the way of the comprehensive information of the Bundestag and of the Bundesrat." ${ }^{20}$ Parliament's right to be informed by the government is a requirement necessary for democratic decision-making and is something the court saw itself called to protect, even while acknowledging the prerogative of that same parliament to-primarily-decide how to preserve its own decision-making powers.

The German Constitutional Court also took this democracy-preserving approach in its ruling in the main proceedings on the ESM. Despite the its dismissal of the main claims, the court insisted that parliament take the steps necessary to prevent German voting rights from being suspended, ${ }^{21}$ as such a suspension would lead to Germany being bound by decisions that were not legitimized by parliament. This became relevant in relation to Article 4(8) of the ESM Treaty, which provides for the suspension of voting rights of a member that fails to meet a capital call on time. According to the court, not meeting a capital call on time and the subsequent suspension of German voting rights would also mean that "the German Bundestag's participation in the decisions of the bodies of the European Stability Mechanism, which is required under national law, would fail for so long as the voting rights are suspended." 22 Accordingly, "this would mean that the decisions taken in this period would not be legitimized and monitored by the German Bundestag." 23 The Court stepped in to prevent such an infringement on the democratic process by ordering the parliament to use its budgetary powers to ensure that Germany would always be able to meet capital calls.

The German Constitutional Court was not the only Member State court to emphasize the need for courts to show deference to parliament and the importance of courts limiting their own role to protecting the democratic process. While less explicit than the German Constitutional Court, the Irish Supreme Court also concerned itself with such matters. This was especially the case in the Irish Supreme Court's review of whether the ESM's emergency voting procedure and option to suspend voting rights limited the possibility of Irish democratic decision-making to an unacceptable extent. The Irish Supreme Court observed that-under the emergency voting procedure and the stripping of voting rights when a country fails to meet its payments - decisions could be taken that would bind Ireland without the State's consent. This raised the concern that the ESM could shut down the democratic process within Ireland. Nevertheless, the court found that, because the only decisions possible in such cases did not "(i) determine policy, (ii) create a mechanism of policy determination, or (iii) increase the State's specified maximum financial contribution," 24 they were thus not important enough to entail an unacceptable transfer of decision-making power. ${ }^{25}$ In effect, the court considered what the impact would be of ESM decisions taken under the emergency voting procedure or if

\footnotetext{
${ }^{19} I d$. at para. 228.

${ }^{20}$ This was one of the two requirements the court outlined for determining the constitutionality of the Treaty. The other requirement was that the government had to ensure under international law that "no provision of th[e] Treaty may be interpreted in a way that establishes higher payment obligations for the Federal Republic of Germany without the agreement of the German representative." See Judgment of Sept. 12, 2012 at page 4.

${ }^{21}$ Bundesverfassungsgericht [BVERFG] [Federal Constitutional Court], Case No. 2 BvR 1390/12, para. 158, (Mar. 18, 2014), http://www.bverfg.de/e/rs20140318_2bvr139012en.html [hereinafter Judgment of Mar. 18, 2014].

${ }^{22} I d$. at para. 199.

${ }^{23} I d$.

${ }^{24} J$ udgment of Oct. 19, 2012 at para. 17.ix.

${ }^{25} I d$. at para. 17.xii.
} 
Ireland was stripped of its voting rights on the ability of the Irish democratic process to regulate certain matters deemed to be at the core of the right to democracy. Because the court found that decisions by the ESM in these cases would not affect policy, policy determination, or the State's maximum financial contribution, it ruled that the ESM's decision-making powers did not infringe on Ireland's right to determine matters at the core of Irish sovereignty. The court's analysis shows a concern for the preservation of democratic decision-making within the Irish state and a focus on preserving the space for democracy.

The Dutch District Court in The Hague was the most deferential of all the courts studied. Because the Dutch constitution prohibits judicial constitutional review of legislation, the Dutch District Court ruled that it had no competence to review the claim of unconstitutionality brought before it. ${ }^{26}$ Interestingly, the court nevertheless took the opportunity to emphasize the importance of political debate on the matter of the ESM and pointed out that the complaints brought by the plaintiffs have the possibility of being the subject of debates that have beenor will be-conducted throughout the legislative process. ${ }^{27}$ While not implying that the court would have interfered if due democratic process had been lacking, the court nevertheless found it relevant to mention the importance of the availability of such a democratic process "conducted by the current representatives of the people, a process in which the judge cannot intervene." 28

In addition to this attention to constitutional review of the parliament's ratification of the EMS Treaty, the Dutch District Court entertained a claim from the plaintiffs based on international law. The plaintiffs argued that the right to democracy encapsulated in a number of international human rights treaties was violated by the fact that the government put the ESM Treaty to the parliament to be ratified without waiting until after the parliamentary elections planned for later that year. The Dutch court dismissed this claim, holding that the members of parliament are elected directly by the Dutch electorate, and that it could thus be concluded that the Dutch population was represented by parliament in their decision on the ESM Treaty. ${ }^{29}$ Thus, even when the Dutch District Court did review the parliamentary ratification of the ESM against higher norms, it kept its review focused on democratic process-based considerations.

The Estonian Supreme Court's review of the ESM was more substantive than that of the German, Irish, and Dutch courts. Further, the Estonian Supreme Court was the court that departed the most from Ely's process-based review. Instead of focusing on whether the conditions for democratic procedures were still in place or on whether the decisions taken without the consent of the state unacceptably limited democratic possibilities within the state, it engaged in a proportionality analysis to set out the conditions under which it would defer to the legislature's decision on the ratification of the Treaty. The Estonian Supreme Court started by finding that the emergency voting procedure in the ESM Treaty interfered with the constitutional budgetary rights of the Estonian parliament. It also interfered with the "state's financial sovereignty ... and the principle of a democratic state subject to the rule of law due to the possibility that at the request of the ESM the callable capital must be paid in the future." ${ }^{30}$ Nevertheless, even in the rather substantive proportionality review employed by the court to evaluate whether the interference was justified, ${ }^{31}$ considerations of democracy played an important role. As is common in such review, the court considered that so long as the interference pursued an objective that was legitimate in a democratic state, and so long as the interference was necessary, appropriate, and reasonable, ${ }^{32}$ the court would hold that the legislature acted within the scope of its constitutional power. The court

\footnotetext{
${ }^{26}$ Judgment of June 1, 2012 at para. 3.3.

${ }^{27} I d$. The fact that the court engaged with the constitutional challenge in this way, despite the prohibition on constitutional review, is remarkable.

${ }^{28} I d$. (translated by author).

${ }^{29}$ Id. at para. 3.4.

${ }^{30}$ Judgment of July 12, 2012 at para. 206.

${ }^{31} I d$. at para. 207.

${ }^{32} I d$. at para. 209.
} 
ruled that all these conditions were met, and thus that the emergency voting procedure of the ESM Treaty did not violate the Estonian Constitution. ${ }^{33}$

Largely, these ESM cases are examples of judges engaging in constitutional review with the aim of protecting the proper functioning of democracy. Particularly, the German, Irish, and Dutch courts note this aspect in their rulings. Additionally, the German and Irish courts note their duty to intervene when they find that the challenged measure interferes with possibilities for democratic processes. The following Part asks whether this method of constitutional review is really as devoid of substantive decisions as Ely proposes and as the courts studied here seem to assume. I consider a critique of Ely's theory that highlights the inherently substantive nature of democracy itself, and I propose to refine his theory by devoting more attention to avenues of contestation in the judicial decision-making process.

\section{C. "Democracy" as Substantive Criteria and the Need for Contestation}

In process-based review, judges use their competence in constitutional review to ensure the basic functioning of democratic processes, and they make clear that it is not their role to substitute the legislature's decisions on political and moral values with their own. In other words, process-based review insists that courts act purely in their role as constituted power. The current Part first explores a critique of the assumption that process-based review avoids courts acting as constituent power and concludes by proposing an extension of Ely's theory that addresses this critique.

\section{The Substantive Nature of Democracy and the "People"}

The attempt to eliminate all substantive judgment from constitutional review by having judges focus only on protecting the functioning of the democratic process runs up against a problem: The inherently substantive nature of democracy itself. The very choice to focus on preserving the functioning of the democratic process is underpinned by a normative judgment on the value of democracy. There is, in other words, a reason why we care about democratic procedures. According to constitutional scholar Lawrence Tribe, if process is to be valued, it "must be valued not only as a means to some independent end, but for its intrinsic characteristics." 34

Ely does not provide a coherent, underlying theory to justify his interest in democratic procedures. Nevertheless, it is clear that Ely feels strongly that unelected judges do not have the legitimacy to make substantive decisions. Instead, such decisions must be made by the people-represented by the legislature. In what follows, I look to the body of scholarship in constitutional theory on constituent and constituted powers to further flesh out the theory of democracy that underlies Ely's convictions. Important parallels can be drawn between the theory on constituent and constituted powers, on the one hand, and the role of the people as the legitimate author of substantive decisions, on the other. Yet, we will see that instead of providing us with a final ground for the democratic process, this investigation reveals that the democratic order is-in the end-ungrounded.

\section{Constituent and Constituted powers}

The theory of constituent and constituted powers can be traced back to eighteenth century Enlightenment thinking ${ }^{35}$ and is traditionally linked to Emmanuel-Joseph Sieyès, the French abbot and revolutionary. Sieyès developed the claim that the final source of political authority can only be the people, not the monarch. ${ }^{36}$ It is the people, not the monarch, who author the constitution, and it is the people, not the monarch, from which the constitution derives its political

\footnotetext{
${ }^{33} I d$. at para. 210 .

${ }^{34}$ Laurence Tribe, The Puzzling Persistence of Process-Based Constitutional Theories, 89 YALE L.J. 1063, 1070-71 (1980).

${ }^{35}$ Loughlin, supra note 1 , at 219.

${ }^{36}$ Emmanuel-Joseph Sieyès, What is the Third Estate? 126 (M. Blondel trans., Pall Mall Press 1963) (1798).
} 
and legal authority. The people are the constituent power. By virtue of the by-the-people authored constitution, the organs of the state are constituted, and thus these organs are the "constituted" powers. The constituted powers ultimately derive their authority and right to act from the people.

When a constituted power-such as a court-acts, it can only act authoritatively if it acts on behalf of the constituent power that instituted it. We see the primacy of constituent power-the people-acknowledged by the courts - the constituted powers-in the ESM cases. The German Constitutional Court, for example, spoke of the importance of the German parliament as the "representative of the people" ${ }^{\text {" }} 7$ and focused on the right to vote as a guarantee for "self-determination of the citizens" and of "free and equal participation in the exercise of public power in Germany." ${ }^{38}$ In the Irish Supreme Court's decision in Pringle, the court noted that "the powers that are given to the organs of the State under the Constitution are for the common good of the people of Ireland" 39 and instructed the reader that "the common good of the Irish people is the ultimate standard by which the constitutional validity of the conduct of foreign affairs by the Government is to be judged." 40 The Estonian Supreme Court buttressed its authority by reference to its constitutional obligation to preserve "the Estonian people, the Estonian language and the Estonian culture through the ages." ${ }^{11}$ By ruling on behalf of the people, the courts here echo the role of constituted power that Ely also argued for: The constituted power may act only insofar as it is authorized by the people to act.

Nevertheless, there is a paradox at the heart of this traditional view of constituent and constituted power. This paradox presents itself if we attend to the "act whereby a people is a people." 42 In a democracy with popular sovereignty, it is supposed to be the people who make substantive decisions. Yet, at the same time, this group who must decide does not exist until a political community has been instituted. And how is the political community to be created when its creation presupposes a decision from the very community that is yet-to-be created? Jean-Jacques Rousseau pondered this question more than two hundred years ago and argued that the solution to this paradox could be found in the intervention of a lawgiver-a wise, transcendental figure who posits the will of the people who are yet-to-be. ${ }^{43}$ "Someone must seize the initiative" 44 to speak on behalf of a multitude in a way that projects the multitude as something more than just a group of people. The people as a multitude cannot speak as a unity; instead, it is the lawgiver who must speak on behalf of the unified people. ${ }^{45}$ The people as a unified we-this supposed constituent power-must itself be called into being by someone or something that is already constituted. ${ }^{46}$

Yet, this cannot finally solve the paradox, as the one who seizes the initiative is-in a democracy-dependent on the yet-to-be constituted people to verify the accuracy of their initiative. The paradox is not solved; instead, we remain in a moment of interdependence in between the people and the lawgiver: A lawgiver is needed to institute the people and a people is needed to verify who the true lawgiver really is. ${ }^{47}$ From this perspective, we see that constituted power

\footnotetext{
${ }^{37}$ Judgment of Mar. 18, 2014 at para. 162.

${ }^{38} I d$. at para. 159.

${ }^{39}$ Judgment of Oct. 19, 2012 at para. 17.ii (emphasis added).

${ }^{40} I d$. at para. 14.xvii (emphasis added).

${ }^{41}$ Judgment of July 12, 2012 at para. 201.

${ }^{42}$ Jean-Jacques Rousseau, That it is Always Necessary to Return to a First Convention, in On the Social Contract or Principles of Political Right, in 1 The Broadview Anthology of Social and Political Thought 668 (Baily et al. eds., Broadview Press 2008) (1762).

${ }^{43}$ Jean-Jacques Rousseau, The Law-Maker, in On the Social Contract or Principles of Political Right, in 1 THE BROADVIEW Anthology of Social And Political Thought, supra note 42, at 677-79.

${ }^{44}$ Hans Lindahl, Constituent Power and Reflexive Identity: Towards an Ontology of Collective Selfhood, in THE PARADOX OF Constitutionalism: Constituent Power and Constitutional Form 9 (M. Loughlin \& N. Walker eds., Oxford Univ. Press 2007).

${ }^{45}$ Loughlin, supra note 1 , at 231-32.

${ }^{46}$ Luigi Corrias, The Legal Theory of the Juridical Coup: Constituent Power Now, 12 German L. J. 1553, 1571 (2011).

${ }^{47}$ Bonnie Honig, Between Decision and Deliberation: Political Paradox in Democracy Theory, 101 AM. POL. SCI. REV. 1,6 (2007).
} 
cannot follow from, and remain purely dependent on, constituent power. Instead, constituent and constituted power are intertwined in a reciprocal relationship, whereby the constituent power depends on a previously constituted power to be called into being, and constituted power derives its existence and authority from the constituent power.

It is tempting to view this reciprocity between constituent and constituted power as limited to the moment of institution of the political community. We might grant that constituent power is not a prior, naturally existing phenomenon. But, perhaps, for all moments after its calling into being, we can see it as independent, static, and pre-given. We might imagine that the constituent power, after being called into existence, becomes detached from and unaffected by any further acts of representation and constitution. Thus, while it might be necessary for an original seizing of the initiative thereafter, all acts of constitution derive their authority from this pure, original moment. In this way, we might accept that while the paradox of the people is intractable at the beginning of a political order, the paradox disappears once the social fact of a political order has been established. In other words, while the constituent and constituted power might be interlinked and interdependent when the political order is instituted, thereafter, all acts of the constituted power are merely acts of "boundary enforcement" of the initial political order set out at the moment of institution. ${ }^{48}$

\section{The Enduring Reciprocity Between Constituent and Constituted Powers}

The idea that constituent power is active only at the creation of a political community and thereafter is subsumed by constituted power is a tempting view, but one we must resist. Contemporary views of constituent power rightfully challenge this limitation of interdependence to the moment of institution. ${ }^{49}$ Indeed, every day, the people are inescapably re-instituted in a way that cannot be captured by a static constitutional order and in a way that cannot be justified by reference back to some original moment of institution. Every day, the people are re-instituted as new members are born or immigrate, or as old members die, leave, or simply change their beliefs and opinions. ${ }^{50}$ And every day, the people must create itself anew by determining what it recognizes as the true original moment of its institution and how its boundaries should rightfully be drawn. ${ }^{51}$ As Hans Lindahl noted, "boundary enforcement and constitution are always intertwined," and an enforcement that is purified of all new constitutions is as impossible as a constitution purified of claims to enforce some real or right essence. ${ }^{52}$ Instead, each act of enforcement of the people includes, within it, an act that inaugurates that people, and each act of inauguration, is justified with an appeal to enforce a particular boundary.

The paradox of the people is thus not only a paradox that arises at the moment a political or legal order is instituted but is a recurring paradox of politics. The imposition of a lawgiver as the representative of the people is not a one-off imposition at the beginning-it is an imposition each day anew and one that ultimately depends, day after day, on the people to recognize it as the legitimate lawgiver. The people thus remain dependent on constituted powers to the extent that the people "cannot act as constituent power without being represented by a constituted power." ${ }^{3}$ The key point for our purposes, as Corrias explains, is that "the court is such a constituted power and such a representative." 54 This places courts at the center of a "political struggle that involves a challenge to the claim by constituted authorities to act as the authoritative voice of the people." 55

\footnotetext{
${ }^{48}$ Hans Lindahl, Law's “Uncanniness”: A Phenomenology of Legal Decisions, 2 Neth. J. Legal Phil. 137, 144 (2009).

${ }^{49}$ See, e.g., Corrias, supra note 46; Honig, supra note 47; Lindahl, supra note 48, at 144; Loughlin, supra note 1.

${ }^{50}$ Honig, supra note 47 , at 3.

${ }^{51}$ Lindahl, supra note 48 , at 144.

${ }^{52}$ Lindahl, supra note 48 , at 144.

${ }^{53}$ Corrias, supra note 46 , at 1571 .

${ }^{54}$ Corrias, supra note 46 , at 1571 .

${ }^{55}$ Loughlin, supra note 1 , at 232.
} 
Here, we come to the core challenge to the neutrality of process-based review. In order for a judge to engage in process-based review with the aim of ensuring the preservation of democratic procedures, the judge must refer to the people as the basis of her authority. Yet, the recurrent paradox of democratic politics makes it impossible for the judge to simply refer back to an original moment of institution in order to find the true people. As such, the decision about who belongs to the people and who does not cannot be predetermined by rule or principle; it is not a procedural decision, but a substantive one. ${ }^{56}$ Ruling on behalf of the "German people" or "Irish people" or any other "people" is an ungrounded exclusion of all those who are not considered to belong to that people. In the case of the particular context of the ESM judgments, where the courts point to the people as being represented by the parliament, this means that those individuals not represented by the national parliament are excluded from the courts' conception of the constituent power. We may specifically think here of those living in the state without the right to vote, but also those who live in other states. This decision on who belongs to the people is a substantive one and ungrounded. Not even the constitutional order can provide grounding for this exlcusion. The very claim of what the constitutional order demands has in itself, already, a constituting function. Such boundary enforcement entails boundary creation. Moreover, not only is this decision as to who the people actually are not finally grounded on any particular norm or fact, it is one that contributes to the construction of the people it claims to represent-thus putting the court in the position of constituent power.

This brings us to the original dilemma of constitutional review that Ely tried to solve: How to justify that, in a democracy, an unelected judiciary can use its interpretation of the constitution to overrule democratically adopted legislation. Ely argued that process-based review is the only way to legitimate this role for the judge, because with it, the judge avoids substantive decisions and instead focuses only on the democratic procedure-something that courts are particularly qualified to do. ${ }^{57}$ Yet, if substantive, political decisions are inherent even in process-based review, Ely's argument seems to miss its mark. It is no longer clear that process-based review can be promoted only because of its supposed value-free adjudication.

\section{Internalizing Contestation}

In the remainder of this Article, I present the argument that Ely's attempt to legitimize judicial constitutional review can be salvaged, but only if we recognize that it is incomplete. The problem is not that protecting democratic procedures requires substantive judgment, but that Ely presents no clear theory for how the judiciary should engage in such substantive review, based on a normative conception of democracy. First, I will review Ely's argument in favor of judicial constitutional review of legislation against legislative supremacy. I will show that this argument stands, regardless of the substantive nature of the judgment involved in constitutional review. Second, I propose an expansion of Ely's theory. If judges cannot avoid making substantive decisions, then they should do so in a manner that fits with the aim of process-based judicial review. This entails ensuring that the political outsider - the other - is not excluded by political insiders from the democratic decision-making process. Importantly, this principle must be extended to the judge's own decision-making process.

\section{Preserving the Legitimacy of Constitutional Review}

As mentioned above, Ely's argument in favor of constitutional review had to do with his conviction that courts occupy a unique institutional position—namely, that of a political outsider that is

\footnotetext{
${ }^{56}$ The argument is not that there aren't any principles that could guide this decision-for example, the "all-affected principle." Yet, all principles must be interpreted before they can be applied to a concrete situation. This interpretation requires decision. See generally William W. Sokoloff, Between Justice and Legality: Derrida on Decision, 58 PoL. RES. Q. 341,341 (2005).

${ }^{57}$ ELY, supra note 2, at chapters 3 and 4.
} 
not a direct participant in the political game. According to Ely, this outsider position makes courts the best suited branch of government to ensure that the political insiders do not manipulate the rules of the political game to exclude participation by outsiders. ${ }^{58}$ As Ely so wryly put, "lawyers do seem genuinely to have a feel, indeed it is hard to see what other special value they have, for ways of insuring that everyone gets his or her fair say." ${ }^{9}$ To this justification for judicial review, Ely added a conviction that the judiciary would be able to protect against the exclusion of outsiders in a purely procedural manner.

The question is whether this second claim is necessary for the first to stand. Does the substantive nature of courts' judgments detract from the suitability of courts to ensure the fairness of the political rules of the game? For the sake of argument, let us accept that some branch should be entrusted with this guardianship - that one of the three branches of government should be the one to have the final word on the constitutionality of the law. We can then argue that, even though the courts might have to engage in substantive decisions to execute this guardianship, the institutional position of the courts does still make them better suited to this guardianship than the legislature or the executive. Far more than is the case for the legislature or the executive, the courts are indeed removed from the current political constellation of insiders and outsiders and are, in any case, not directly affected by their own rulings. ${ }^{60}$ Thus, while perhaps not only procedurally-oriented-if we accept that substantive aspects of a decision are inevitable - the courts, unlike the legislature and the executive, are at least independent of the political procedures they are reviewing. This is not to say that the courts protect the functioning of democracy objectively or neutrally, but that they do it better than the alternative branches would. Courts may not be perfectly suited to fulfilling the role of constitutional review, but they do have a comparative advantage over all other branches of government.

The fact that decisions on what is fair, open, and free of bias must also grapple with questions about who the true people are who have the right to participate in that democracy, does not undercut the unique position of the judiciary as a player outside of the directly political arena. It does not hinder the judiciary's unique ability to ensure that the political arena remains democratic. ${ }^{61}$

\section{Avenues of Contestation}

Even if one accepts that the judiciary is at least better suited than other branches of government to ensure laws do not exclude the outsiders of politics, this does not excuse us from the question of how the judiciary can best make the substantive decisions it must inevitably engage in. If it is true that decisions on democratic procedure are also always substantive, we can no longer rely only on a technocratic version of the judge who uses her skills to tweak the democratic system to be the objectively best possible system. Instead, a practice of judicial decision-making is necessary to account for the substantive aspects in process-based review. I propose here that this judicial practice should be informed by the value Ely gives to participation in the political process. To support this claim, we must understand why Ely privileges participation in the political process. Subsequently, I argue that the reason for valuing participation in the political process is just as valid for the judicial process.

Ely saw his process-based review as dedicated to preventing political insiders from permanently excluding political outsiders from the possibility of gaining political power. His claim that it is important to prevent the entrenchment of power to "ensure that the political process ... [is] open to those of all viewpoints" 62 is based on the assumption that there is intrinsic worth in making sure

\footnotetext{
${ }^{58} \mathrm{ELY}$, supra note 2 , at 103.

${ }^{59}$ ELY, supra note 2, at 102 .

${ }^{60}$ The exception being cases in which the judiciary has to decide on its own powers.

${ }^{61}$ Ely briefly mentioned that judges' evaluations will be "full of judgment calls." ELY, supra note 2, at 103. Yet, he paid little attention to the implications of this acknowledgment and did not see these judgment calls as substantive, political decisions.

${ }^{62}$ ELY, supra note 2, at 74 .
} 
all viewpoints can participate in political decision-making. ${ }^{63}$ Ely himself does not elaborate much more on this intrinsic worth. Nevertheless, I submit that Ely's position on the importance of participation can be grounded in Claude Lefort's famous observation that the key to modern democracy is ensuring that the place from which political power is exerted is not permanently occupied by some force that is seen as the full and final materialization of the people. Unlike previous forms of government, where some creed, body, or identity - for example, God, the King, or "reason"was the final guarantor, in a democracy, this place of power must remain empty. ${ }^{64}$

Lefort argued that the hallmark of modern democracy is a tension between the legitimacy of the people as constituent power and the fact that the place of constituent power must never be permanently occupied by any one constellation of the people. On the one hand, democratic legitimacy is based on the sovereign power of the people as the constituent power; but on the other hand, no one idea of this people can be put beyond contestation if we are to avoid the pathology of totalitarianism. In a democracy, no person, party, or belief must inhabit the seat of power permanently and without challenge. ${ }^{65}$ Democracy requires that the people can challenge the identification of who the true lawmaker is and can disagree about her authority for lawgiving. ${ }^{66}$ Any claim to being people or lawgiver can thus not help but inaugurate a politics of contestation. ${ }^{67}$ Individuals will disagree over the veracity and appropriateness of claims to knowing the true people or true lawgiver, and, if the system is to remain democratic, such disagreement must remain possible. ${ }^{68}$ Lefort proposes that democratic legitimacy must, ultimately, depend on an incessant debate about who the people are and who the legitimate voice of the people is ${ }^{69} \mathrm{~A}$ debate "necessarily without any guarantor and without any end."70

In fact, Lefort's position can be seen as an acknowledgment—and appreciation-of the reciprocal relationship between constituent and constituted power described above. ${ }^{71}$ Lefort's debate without any end as to who the true people are recognizes the changeable nature of the constituent power, even while recognizing the importance of this constituent power for the legitimacy of constituted powers. Whereas Sieyès saw the people as a concrete and discrete group of people and claimed that the people preceded the political order and were not and must not be subject to any constitution, ${ }^{72}$ Lefort argues that the people must be viewed more symbolically. In fact, the "people-as-one," ${ }^{73}$ as a unified actor able to speak and act authoritatively does not exist in reality, according to Lefort. Even at the very point in time that the people come together during elections - the moment supreme - to express their voice, at this very moment the people dissolve into a multitude and the voter becomes a mere statistic. ${ }^{74}$ Thus, unlike Sieyès, Lefort does not see the people as a stable, pre-given entity.

Ely's emphasis on participation of all viewpoints in the political debate shows recognition of the importance of contestation similar to Lefort's but fails to extend far enough. Whereas Ely sees participation as important only in the realm of formal democratic politics, Lefort's concept of democracy stretches much further. Lefort's democracy relies on an entire symbolic order, ${ }^{75}$ in

\footnotetext{
${ }^{63}$ This argument is similar to Ely's admission that "[p]articipation itself can obviously be regarded as a value." ELY, supra note 2, at 75. Yet, Ely fails to recognize that this undermines his claim that process-based review can avoid substantive choices.

${ }^{64}$ Claude Lefort, Democracy and Political Theory 17 (David Macey trans., Polity Press 1988).

${ }^{65} \mathrm{Id}$.

${ }^{66}$ Honig, supra note 47 , at 6.

${ }^{67}$ Honig, supra note 47 , at 6.

${ }^{68}$ Honig, supra note 47 , at 6.

${ }^{69}$ See Van Roermund, Questioning the Law?, in LAw AND AgOnistic Politics (Andrew Schaap ed., Routledge 2009); Andrew Schaap, Introduction to Law And Agonistic Politics 7 (Andrew Schaap ed., Routledge 2009).

${ }^{70}$ LEFORT, supra note 64 , at 39.

${ }^{71}$ Loughlin, supra note 1 , at 234 .

${ }^{72}$ SIEYĖS, supra note 36 , at 126.

${ }^{73}$ LEFORT, supra note 64 , at 13.

${ }^{74}$ LEFORT, supra note 64 , at $18-19$.

${ }^{75}$ LEFORT, supra note 64 , at $14,16$.
} 
which "indeterminacy is welcome[d] and preserve[d]." ${ }^{\prime 6}$ Instead of limiting the need for participation and contestation to the formal political realm, this perspective justifies the extension of participation and contestation over who the true people are to all fora where the reciprocal relationship between constituent and constituted power plays out-including the judiciary. As it is impossible for any constituted power to act on behalf of a constituent power, without also constituting the constituent power, it is imperative that all actions taken by constituted powers, including judicial decisions, remain open to the contestation Ely so greatly valued. Avenues for constitution must be created within institutions to ensure that the people, represented by democratic institutions, remain open to alternative formulations.

\section{Three Proposals for a More Complete Process-Based Constitutional Review}

The last section of this Part explores what such an approach might concretely mean if we apply it to the cases analyzed above. I propose three ways the courts in these Eurozone crisis measure cases could have allowed for more avenues of contestation to feed into their decision. I will also discuss to what extent the courts made use of these avenues. In general, we can conclude that the position taken by the German, Irish, Estonian, and Dutch courts did not attend to this notion of contestation within the judicial decision-making process. These courts saw the people as a static entity, pre-determined by the relevant national constitution, and failed to allow this conception to be contested in their decision-making process.

First, in order to promote the contestation discussed above, courts could nuance the grounds given for their deference to the legislature's decision-making process by explicitly noting who the legislature's conceptions of the people exclude. Both the German and the Dutch courts explicitly saw their roles as limited because of the legislature's duty to weigh the different rights and interests involved in the case. Yet, due to the fact that, in these countries, only citizens of that particular state can vote in parliamentary elections, the residents of those states who are not citizens and the residents of debtor states have no formal avenue to make their voices heard in the legislative decision-making process. At the very least, courts should acknowledge the restricted nature of the people who were able to participate in the national political process.

This proposal calls on judges to realize that their conception of the people could have been different. It is not inconceivable that the ESM courts could have looked beyond the "national box"77 to take account of those most affected by their decision: Residents of debtor Eurozone states. The crisis measure under review arguably has the largest effect on the residents of those states potentially subjected to the terms and conditions of ESM loans; those people who both rely on the ESM to prevent the failure of their economies and whose lives and livelihoods are affected as a result of the strict terms of the loans given.$^{78}$ It is these people, whose lives were also immediately and directly affected by the ESM, and who are not represented by creditor state legislatures or creditor state courts. Courts should acknowledge this exclusion by noting in their decisions that the legislature's weighing of rights and interests was, in fact, incomplete. While this acknowledgment does not change the outcome of the decision itself, it lays bare the limited notion of the people on whose behalf the decision is made, and thus opens this notion up to subsequent contestation.

My second proposal goes a step further and will take more space to describe. Courts can promote contestation within their decision-making processes by actively entertaining challenges to their conception of the people and to the knowledge claims considered common knowledge by that people.

\footnotetext{
${ }^{76}$ LEFORT, supra note 64, at 16.

${ }^{77}$ Bundesverfassungsgericht [BVERFG] [Federal Constitutional Court], Case No. 2 BvR 2728/13, Dissenting Opinion Lübbe-Wolff, para. 28, (Jan. 14, 2014), https://www.bundesverfassungsgericht.de/e/rs20140114_2bvr272813en.html.

${ }^{78}$ See Gonzalo Cavero \& Irene Martín Cortés, Oxfam International, The True Cost of Austerity and INEQUAlity: GReEce CASE STUdy 5 (2013) (showing that the suicide rate in Greece increased 26.5\% from 2010 to 2011 and has increased by $104.4 \%$ in the case of women). See also Lucy Rodgers \& Nassos Stylianou, How Bad Are Things for the People of Greece?, BBC NEws (July 16, 2015), https://www.bbc.com/news/world-europe-33507802.
} 
The German Constitutional Court explicitly refused to do this. The court acknowledged that it was a "subject of great controversy among economic experts," whether the entire economic and social system would be under threat if the ESM was not adopted but held that the it must defer to parliament's assessment on these matters. ${ }^{79}$

A number of judges in the Estonian case, however, did express some competing knowledge claims. Ten of the nineteen judges on the Supreme Court expressed their dissents to part or all of the decision in five dissenting opinions. ${ }^{80}$ It was in these dissenting opinions that the judges expressed their concerns about the concealed purposes of the ESM treaty ${ }^{81}$ and about the emotional nature of the arguments used to justify the majority's decision. ${ }^{82}$ In Judge Jaak Luik's dissenting opinion, for example, the entire premise of the ESM was called into question:

[R] egardless of how hard I try, I cannot understand how emergency assistance/assistance increasing the burden of debt of a state/bank allows in the long run to guarantee the economic and financial sustainability thereof and of the entire euro group .... So I find that the beliefs of the Supreme Court en banc in the mystical efficiency of the ESM in safeguarding the prosperity of the euro area Member States, including Estonia ... do not fit in the boundaries of intelligent probability. ${ }^{83}$

These dissents show that the Estonian court was able to provide space to competing knowledge claims. Yet, it is hard to argue that the alternative knowledge claims given space by the judges in this case were signs of contestation by those challenging the judges' conceptions of the people as a national people. Instead, these claims seem linked to discussions about the necessity and utility of the ESM within the national context. If the courts were really to allow contestation of the people into their decision-making processes, they would have had to also take account of arguments from those not able to participate in decision-making through the formal political channels. A conceivable step in this regard would have been for the courts to give some mention of the human rights violations expected as a result of the conditionality required by the ESM. The conditionality requirements for states receiving assistance often raise considerable human rights concerns relating to socio-economic rights, such as the right to health, housing, and work-in the International Covenant on Economic, Social and Cultural Rights - and the rights to collective bargaining, the entitlement to social security guaranteed by the European Charter of Fundamental Rights, and the fundamental right to protection of human dignity that informs the entire Charter. ${ }^{84}$

This proposal goes further than the first, as it calls on the courts to go beyond a mere acknowledgment of the exclusionary nature of their conception of the people and instead actively entertain alternatives to this conception. At the same time, this proposal should not be interpreted as necessarily leading to a radical change in the legal holding of the decision-though it may. Nevertheless, a broader account of alternative conceptions of the people and alternative knowledge claims in the court's decision would have at least two democratically beneficial effects: Those excluded from the political forum would be given a voice in the legal forum, and it would send a message to these groups that the court is aware of potential claims to be made on their behalf in a way that can act as an invitation to further litigation. Such further litigation could help overcome the problems inherent in expecting a judge to speak on behalf of the other, whom the judge may not always be aware of.

\footnotetext{
${ }^{79}$ Judgment of Sept. 12, 2012 at para. 271.

${ }^{80}$ Dissenting Judge Villu Koye disagreed with the majority on the issue of the admissibility of the plaintiff s claim but, nevertheless, supported the majority's decision on the merits of the case.

${ }^{81}$ Judgment of July 12, 2012, Dissenting Opinion Jüri Ilvest.

${ }^{82} I d$. Dissenting Opinion Henn Jõks et al. para. 0.

${ }^{83} I d$. Dissenting Opinion Jaak Luik, para. 19.

${ }^{84}$ For a more detailed analysis of the rights possibly violated by the conditionality required by the ESM, see Margot E. Salomon, Of Austerity, Human Rights and International Institutions, 21 EUR. L.J. 521, 521 (2015).
} 
My third proposal argues for revisiting the use and purpose of amicus curiae briefs. Such submissions from friends of the court allow other voices into the judicial process in a way that lets the other speak for himself. With the exception of the Irish Supreme Court, none of the courts discussed here accept amicus filings as a regular practice. If the courts in these cases had the practice of admitting amicus curiae briefs, a formal avenue would be present for the inclusion of voices excluded from the formal political process. A step further would have been for these courts to specifically invite underrepresented and unrepresented groups affected by the outcome of the case to submit amicus briefs to aid the court in their deliberations. In the challenge to the ESM before the Estonian Supreme Court, the court invited certain scholars to submit their expert opinions on whether the ESM Treaty violated the Estonian constitution. ${ }^{85}$ Yet, it is important for the amicus practice to be extended beyond scholarly arguments-however useful — to include submissions from those who have been excluded from current dominant constellations of the people in ways that allow them to participate in the discursive struggle of legal interpretation.

These suggestions provide a possible way forward for judges to promote contestation of the notion of the people in a way that expands Ely's concern with participation to the very process of judicial decision-making itself.

\section{Conclusion}

The cases challenging the European Stability Mechanism in Eurozone creditor states show the concern courts have with protecting and promoting democratic contestation and, in doing so, show how courts view their own legitimacy as linked to this democratic concern. Ely's theory of process-based review provides the theoretical basis for understanding how attention to democratic contestation contributes to the legitimacy of courts reviewing legislation against constitutional norms. Ely argues that, by avoiding substantive questions of values and morals courts can issue judgment on that which they are most competent to assess - the openness and fairness of the rules of the political game-while avoiding the imposition of their own morals and values. Yet, as my discussion of the constitutional theory of constituent and constituted powers shows, no form of constituted power can avoid some exercise of constituent power. In other words, even a processbased approach cannot avoid substantive judgments about who the right to democracy applies to - the people - and what exactly democracy entails. The presence of substantive judgment does not undermine Ely's argument in favor of process-based review, but it does mean that attention must be paid to the process of the judicial decision-making itself. For the judiciary to maintain its allegiance to the preservation and promotion of democratic procedures, it is important for the judiciary's own decision-making procedure to be informed by democratic values that ensure an openness to the other and an openness to contestation of the construction of the people. Because substantive decisions are inevitable, I propose that the legitimacy of these decisions depends on available avenues for contestation being available in the courtroom. It is only by attending to the input to the judicial decision-making procedure that it is possible to maintain the justification of constitutional review in democracy - namely, the preservation of space for contestation of the current political status quo by those it excludes.

\footnotetext{
${ }^{85}$ Judgment of July 12, 2012 at para. 5.
} 